\title{
THE KÖRMEND GROWTH STUDY 1968 AND 2008: SOMATOTYPES OF THE BOYS
}

\author{
GÁbor A. Tóth ${ }^{1}$, Jenő NÉmeth ${ }^{2}$, PÉter MolnÁR ${ }^{1}$, \\ Csilla Suskovics ${ }^{2}$ \\ ${ }^{1}$ Institute of Biology, University of West Hungary, Szombathely, Hungary \\ ${ }^{2}$ Institute of Sport Science, University of West Hungary, Szombathely, Hungary
}

\begin{abstract}
S
The Körmend Growth Study, a series of cross-sectional anthropological surveys, repeated in every 10 years since 1958, was among the firsts to demonstrate the existence of secular trends in the growth and the maturation of children. In this paper the authors give an overview on the physique of the Körmend boys based on the Körmend Growth Study. Somatotype (physique; defined according to the Heath-Carter anthropometric method) of 6-18-year-old boys, measured in 1968 (K-68) and 2008 (K-008), was analyzed and compared. Significant age-dependent changes in somatotypes were found in both study periods. Secular changes in the somatotype of boys were also observed in this West-Hungarian town.
\end{abstract}

Keywords: somatotype, secular trend, the Körmend Growth Study

\section{INTRODUCTION}

Sheldon's conception of somatotype assumes that it is a trajectory on which a person goes along depending on his genetic and environmental endowment [7]. This statement may also be valid for groups. According to the Heath-Carter method [1] somatotype is a measure of shape and not of size, it represents the phenotype of the individual's body build.

The Körmend Growth Study (KGS) was based on an exclusively large sample and was repeated consistently in every 10 years for over 50 years. In this summary KGS was used to illustrate the age-differences in the somatotypes of boys, 
and to demonstrate secular changes [14,3] in the physique of boys of a small town (Körmend in Hungary) between 1968 and 2008.

\section{MATERIALS AND METHODOLOGY}

Körmend is a West-Hungarian town. The KGS was started in 1958 by professor Eiben (1931-2004). The principal field of his scientific research activity was the growth and maturation of children and the secular trend. His favorite work was undoubtedly the KGS. Following the 1958 study, he repeated his investigations in every ten years - K-58, K-68, K-78, K-88. In 1998 the study was carried out by Eiben and Tóth (K-98), and after Eiben's death KGS (K-008) was organized by Tóth $[4,5,6,12,13]$.

The intention of the study was to involve all healthy, 3-18 year-old boys and girls living in the town, i.e. all pre-schoolers and school children. The representation was usually well over 95\%, except in the case of K-98 (76\%), and in the case of K-008 (72\%). Exercising their personality rights, several parents refused to assist the investigation in 1998 and in 2008.

The anthropometric program of the KGS was very extensive. Fifteen body measurements and 10 head and face measurements were taken in 1958 (K-58). In K-68 21 body measurements were taken, and during K-78, K-88, K-98 and $\mathrm{K}-008$, on the basis of the same principle, 23 body measurements formed the anthropometric program.

The instruments used for these investigations were internationally standardized tools: GPM and the Harpenden anthropometer, the Holtain bicondylar vernier caliper, the Lange skinfold caliper, steel tape measure and a portable weighing machine.

The methods and the techniques of the investigations were in accordance with internationally accepted standards described by Martin and Saller [8]. The recommendations of the International Biological Programme, Human Adaptability section, were also taken into consideration [10]. The authors were experienced in these methods. In 1958 it was not possible to measure the skinfolds and the bicondylar widths, but the subsequent series of the KGS had all the body measurements which were required for the estimation of anthropometric somatotypes based on the Heath-Carter method [1]. The somatotype analysis was performed according to this method. Under 6 years of age somatotype was not calculated because in early childhood it was not an adequate measure of physique [4]. Somatotype data for K-68 and K-78 have already been reported by professor Eiben $[2,3]$. 


\section{RESULTS}

Somatotype data are presented in Table 1 and Figure 1. In 1968 the boy's earlychildhood mesomorphy values (the second component) were relatively high. In this age the children were in the ectomorphic mesomorph field. During puberty the ectomorphy component became dominant. Later the mesomorphy and ectomorphy values became balanced with a slight dominance of mesomorphy. The endomorphy component was lagging behind the other two components during the entire pre-puberty and puberty period.

In the 2008 survey the endomorphic mesomorph physique, characteristic for the 6-year-olds, was replaced by a mesomorphic ectomorph physique by the age of 7 . This high-level of linearity correlated with a sudden increase in height [12] and a drastic decrease of the BMI value [11] at the age of 7. The observed changes in BMI could be partially explained by the "trauma" caused by starting the school. After the age of 8 the ectomorphy values were significantly behind the other two components. During puberty the characteristic physique was the mesomorphic endomorph type, then the mesomorphy and the endomorphy values became balanced with a slight dominance of mesomorphy.

Table 1. Differences in the mean values of the somatotype components in the Körmend boys between 1968 and 2008 investigations

\begin{tabular}{|c|c|c|c|c|c|c|c|c|c|c|c|c|}
\hline \multirow[b]{2}{*}{$\mathbf{n}$} & \multicolumn{5}{|c|}{1968} & \multirow{2}{*}{$\begin{array}{c}\text { Age } \\
\text { (years) }\end{array}$} & \multicolumn{6}{|c|}{2008} \\
\hline & $\begin{array}{l}\text { Endo- } \\
\text { morphy }\end{array}$ & & $\begin{array}{c}\text { Meso- } \\
\text { morphy }\end{array}$ & & $\begin{array}{c}\text { Ecto- } \\
\text { morphy }\end{array}$ & & $\mathbf{n}$ & $\begin{array}{l}\text { Endo- } \\
\text { morphy }\end{array}$ & & $\begin{array}{c}\text { Meso- } \\
\text { morphy }\end{array}$ & & $\begin{array}{l}\text { Ecto- } \\
\text { morphy }\end{array}$ \\
\hline 41 & 1.7 & - & 4.1 & - & 2.3 & 6 & 33 & 3.8 & - & 5.1 & - & 2.8 \\
\hline 53 & 1.5 & - & 3.9 & - & 3.1 & 7 & 50 & 3.3 & - & 4.1 & - & 4.6 \\
\hline 53 & 1.7 & - & 3.8 & - & 3.3 & 8 & 60 & 4.5 & - & 4.4 & - & 3.6 \\
\hline 67 & 1.6 & - & 3.7 & - & 3.8 & 9 & 75 & 4.9 & - & 4.8 & - & 3.0 \\
\hline 51 & 1.7 & - & 3.6 & - & 4.0 & 10 & 68 & 4.7 & - & 4.4 & - & 3.4 \\
\hline 60 & 2.1 & - & 3.6 & - & 3.9 & 11 & 49 & 5.0 & - & 4.2 & - & 3.4 \\
\hline 57 & 1.8 & - & 3.7 & - & 3.9 & 12 & 63 & 5.2 & - & 4.3 & - & 3.3 \\
\hline 84 & 2.0 & - & 3.5 & - & 4.2 & 13 & 61 & 4.8 & - & 4.4 & - & 3.2 \\
\hline 85 & 1.9 & - & 3.9 & - & 3.9 & 14 & 72 & 4.3 & - & 4.1 & - & 3.4 \\
\hline 140 & 1.9 & - & 3.6 & - & 3.9 & 15 & 31 & 3.9 & - & 4.4 & - & 3.3 \\
\hline 109 & 2.1 & - & 3.8 & - & 3.6 & 16 & 45 & 4.1 & - & 4.3 & - & 2.5 \\
\hline 89 & 2.3 & - & 3.7 & - & 3.5 & 17 & 48 & 4.1 & - & 4.2 & - & 2.7 \\
\hline 25 & 2.0 & - & 3.6 & - & 3.5 & 18 & 64 & 4.1 & - & 4.1 & - & 2.6 \\
\hline
\end{tabular}



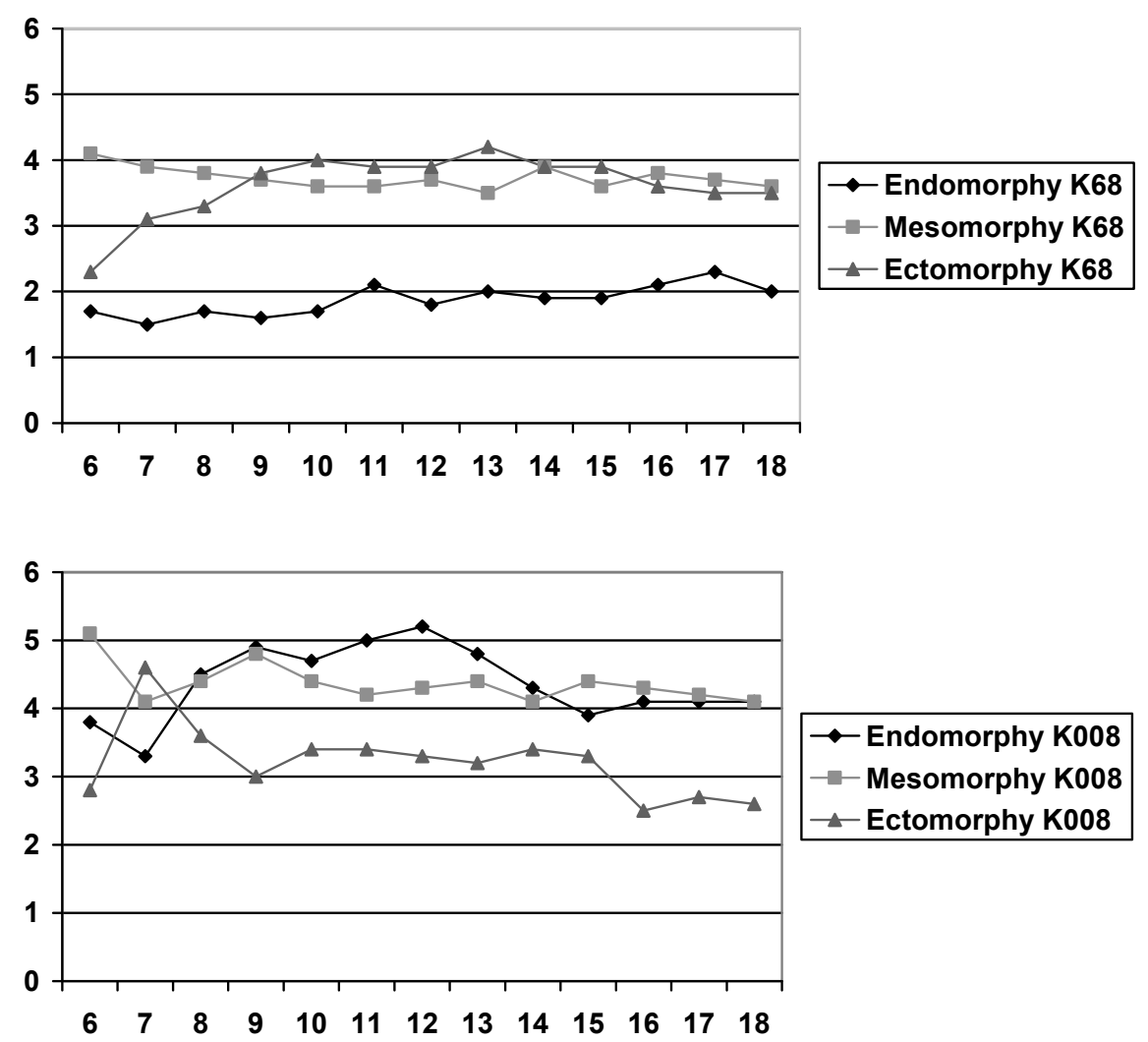

Figure 1. The mean values of the somatotype components in the Körmend boys (K68 and K008 investigations).

\section{DISCUSSION AND CONCLUSIONS}

In 1968, besides the low values of the endomorphy component (an indicator of body fat), the main characteristics of the boys were the linearity and the dominance and balance of the components associated with bone-muscle development. 40 years later ectomorphy and endomorphy values apparently changed place. The dominant component was endomorphy, which characteristically associated with high body fat content and the digestive system. There were no significant changes observed in the mesomorphy component. In contrast, the linearity component was significantly lower than the other two components. The observed changes could be explained based on a possible lifestyle change. A change in the dietary pattern and physical inactivity could result in a significant increase of the abdominal skinfold and suprailiac skinfold measures [9], which caused a change in physique and the dominance of the endomorphy component. 


\section{REFERENCES}

1. Carter, J. E. L., Heath, B. H. (1990). Somatotyping - Development and applications. Cambridge University Press, Cambridge, New York, Port Chester, Melbourne, Sydney.

2. Eiben, O. G. (1985). The Körmend Growth Study: Somatotypes. Humanbiologia Budapestinensis, 16, 37-52.

3. Eiben, O. (1988). Szekuláris növekedésváltozások Magyarországon. Humanbiologia Budapestinensis, Suppl. 6., Budapest.

4. Eiben, O. G. (2003). Körmend ifjúságának biológiai fejlettsége a 20. század második felében. Körmendi Füzetek, Körmend.

5. Eiben, O. G., Tóth, G. (2000). Half-a-Century of the "Körmend Growth Study". Collegium Antropologicum, 24, 2, 431-441.

6. Eiben, O. G., Tóth, G. A. (2005). A Hungarian case of secular growth changes: The Körmend Growth Study. Indian Journal of Physical Anthropology and Human Genetics, 24, 2, 99-108.

7. Sheldon, W. H., Stevens, S. S., Tucker, W. B. (1940). The varieties of human physique. Harper \& Brothers Publishers, New York, London.

8. Martin, R., Saller, K. (1957). Lehrbuch der Anthropologie I. G. Fischer Verlag, Stuttgart.

9. Suskovics, Cs., Tóth, G. (2011). Secular trend in changes of the subcutaneous fat in the Transdanubian region among 3-18-year-old children - unfavourable changes. In: Hughes, M. et al. (Eds.) Research Methods and Performance Analysis. University of West Hungary, Szombathely, 136-145.

10. Tanner, J. M., Hiernaux, J., Jarman, S. (1969). Growth and physique studies. In: Weiner, J.S., Lourie, J. A. (Eds.) Human biology. A Guide to Field Methods. IBP Handbook 9. Blackwell Scientific Publications, Oxford, Edinburgh, 1-76.

11. Tóth, G., Suskovics, Cs. (2011). A BMI értékei a 3-18 éves nyugat-magyarországi gyermekeknél. In: Strédl, T., Nagy, M. (Eds) Egymás mellett vagy együtt?! Selye János Egyetem, Komárom, 102-109.

12. Tóth G., Suskovics, Cs., Buda, B. (2009). Körmendi Növekedésvizsgálat 2008. Folia Anthropologica, 8, 67-70.

13. Tóth, G. A., Molnár, P., Suskovics, Cs. (2012). Gender differences and secular trends in height, pattern of growth and maturation during puberty. Human Biology Review, 1, 1, 16-21.

14. Van Wieringen, J. C. (1978). Secular growth changes. In: Falkner, F., Tanner, J. M. (Eds) Human growth 2. Plenum Press, New York, London, 445-473.

\section{Corresponding author:}

Dr. G. A. Tóth PhD

University of West Hungary, Savaria Campus

Institute of Biology

9700 Szombathely, Károlyi G. tér 4. Hungary.

E-mail: tgabor@ttk.nyme.hu 